\title{
Air-drying temperature changes the content of the phenolic acids and flavonols in white mulberry (Morus alba L.) leaves
}

\author{
Monika Przeor ${ }^{*}$ (D) Ewa Flaczyk ${ }^{1}$ (D) Monika Beszterda² (D) Krystyna Eleonora Szymandera-Buszka ${ }^{1}$ (ID \\ Justyna Piechocka ${ }^{1}$ (D) Dominik Kmiecik ${ }^{1}$ (D) Oskar Szczepaniak ${ }^{1}$ (D) Joanna Kobus-Cisowska ${ }^{1}$ (D) \\ Maciej Jarzębski ${ }^{3}$ (D) Urszula Tylewicz ${ }^{4}$ (D)
}

\begin{abstract}
'Department of Gastronomy Science and Functional Foods, Faculty of Food Science and Nutrition (FFSN), Poznan University of Life Sciences (PULS), 60-624 Poznan, 31 Wojska Polskiego Street, Poland. E-mail: monika.przeor@up.poznan.pl. "Corresponding author.

${ }^{2}$ Department of Food Biochemistry and Analysis, Faculty of Food Science and Nutrition,Poznan University of Life Sciences (PULS), Poland. ${ }^{3}$ Department of Physics and Biophysics, Faculty of Food Science and Nutrition (FFSN), Poznan University of Life Sciences (PULS), Poland. ${ }^{4}$ Department of Agricultural and Food Sciences, University of Bologna (UNIBO), Italy.
\end{abstract}

ABSTRACT: The white mulberry leaves are typically available on the market in dried or encapsulated form. It was assumed in the study that appropriate drying of leaves of the white mulberry is significant for obtaining intermediate products with high content of compounds having anti-oxidative activity. The purpose of the study was to determine the influence of the temperature of mulberry leaves air drying on the content of phenolic acids and flavonols. It has been determined that the content of these compounds in the leaves depended on the drying temperature. Drying at $60^{\circ} \mathrm{C}$ favored release of phenolic acids and flavonols from complexes and/or formation of new compounds. Their total content was $22 \%$ higher than in leaves dried at $30^{\circ} \mathrm{C}$. Drying at $90^{\circ} \mathrm{C}$ reduced the phenolic acid and flavonol content by $24 \%$. The most favorable drying temperature was $60^{\circ} \mathrm{C}$.

Key words: white mulberry leaves, air-drying temperature, phenolic acids, flavonols, Morus alba L.

Temperatura de secagem ao ar altera o teor de ácidos fenólicos e flavonóis em folhas de amoreira branca (Morus alba L.)

RESUMO: As folhas da amoreira branca estão normalmente disponíveis no mercado em forma seca ou encapsulada. Assumiu-se no estudo que a secagem adequada das folhas da amora branca é importante para a obtenção de produtos intermediários com alto teor de compostos com atividade antioxidante. O objetivo do estudo foi determinar a influencia da temperatura de secagem de ar de folhas de amoreira sobre o teor de ácidos fenólicos e flavonóis. Foi determinado que o conteúdo destes compostos nas folhas dependia da temperatura de secagem. Secagem a $60^{\circ} \mathrm{C}$ favoreceu a liberação de ácidos fenólicos e flavonóis a partir de complexos e / ou formação de novos compostos. Seu teor total foi $22 \%$ superior ao das folhas secas a $30{ }^{\circ} \mathrm{C}$. A secagem a $90{ }^{\circ} \mathrm{C}$ reduziu o teor de ácido fenólico e flavonol em $24 \%$. A temperatura de secagem mais favorável foi de $60^{\circ} \mathrm{C}$.

Palavras-chave: folhas de amoreira branca, temperatura de secagem ao ar, ácidos fenólicos, flavonóis, Morus alba L.

The presence of polyphenols in the diet has considerable importance for maintaining homeostasis of the organism and in the prophylaxis of lifestyle diseases. These non-nutritive compounds include phenolic acids (PhA) and flavonols (Fla), and plants such as white mulberry constitute their source. $\mathrm{PhA}$ and Fla are typically reported in a low-molecular, esterified or etherified form with polymers of cellular walls (CHAN et al., 2016; KOBUS-CISOWSKA et al., 2019).

Therapeutic properties of white mulberry leaves (WML) have previously been utilized in the Far East Medicine. Presently, apart from gardening and forestry, they have been applied in food production (PRZEOR \& FLACZYK, 2016; ZOU, 2015), as they are non-toxic to the human organism
(KUJAWSKA et al., 2016). Positive outcomes of WML consumption have been demonstrated with regard to, among others, diabetes, hyperlipidemia, eye and skin diseases, obesity, atherosclerosis, liver cancer (BUTT et al., 2008; IQBAL et al., 2012; QIN et al., 2013).

The WML are typically available on the market in dried or encapsulated form. Adaptation of the suitable technique and drying temperature of the plant material influences their final anti-oxidative activity (LEMUS-MONDACA et al., 2018; PRZEOR \& FLACZYK, 2011).

For the present study it was assumed that suitable processing of white mulberry leaves (Morus alba L.) Polish var. zolwinska wielkolistna 
(WML-P) by means of leaves drying, for the purpose of obtaining the highest possible number of bioactive compounds from them, such as PhA and Fla, is of key significance for the high health-promoting quality of the leaf intermediate products, which may be utilized in the food technology or pharmacy. In the study white mulberry (Morus alba L.) leaves Polish var. zolwinska wielkolistna (WML-P), picked at the tree farm in Pętkowo, near Poznan, were used to prepare extracts from WML-P (WML$\mathrm{Pe})$. Unified material was dried in a convection oven (Rational CCC61/02) at the following temperatures: $30{ }^{\circ} \mathrm{C}(30 \mathrm{AD}), 60{ }^{\circ} \mathrm{C}(60 \mathrm{AD})$ or $90{ }^{\circ} \mathrm{C}(90 \mathrm{AD})$. In the experiment only 3 temperatures were tested to find a preliminary range of the best temperatures for high PhA and Fla content in WML-P. The drying process of WML-P was performed by air drying. HOSSAIN et al. (2010) demonstrated this method of drying to be the most favorable for herbs in terms of retaining anti-oxidative properties. Moreover that type of drying is the most commonly used method of drying herbs in Poland; therefore, it was used in described WML-P production process. Whole, dried leaves were disintegrated in laboratory mill (Retsch GM200, Germany). The powder (10 g) was extracted with distilled water twice $(100 \mathrm{ml}, 40$ $\mathrm{ml}$ ), each time for 5 minutes and filtered. Extraction method and conditions were based on previous own experiments with WML-P. To protect the samples for further analyzes, extracts from WML-P (WML-Pe) were dried by means of lyophilization (Christ Alpha 1-4LSC) and stored in plastic bags in the dark.

Extracts from WML-P (0.4\%) (WMLPe) were injected $(10 \mu \mathrm{l})$ into the Zorbax SB C18 (3,9x150mmx5 $\mu \mathrm{m}$, Agilent Technology, USA) chromatographic column in triplicate. Qualitative and quantitative determination of phenolic acids (PhA) and flavonols (Fla) was determined with HPLC/DAD (Infinity 1290, Agilent Technology, USA) according to (KOBUS et al., 2009; SIGER et al., 2004). The mobile phases were $\mathrm{H}_{3} \mathrm{PO}_{4}(\mathrm{pH}=2.7)$ and $\mathrm{C}_{2} \mathrm{H}_{3} \mathrm{~N}(50 \%)$, and flow rate was $1,5 \mathrm{ml}^{*} \mathrm{~min}^{-1}$. Detection was done based on retention time and UV spectra of standard phenolic acids (Sigma Aldrich): gallic acid (GAL), protocatechuic acid (PRO), 4-hydroxybenzoic acid (HYD), vanillic acid (VAN), chlorogenic acid (CHL), caffeic acid (CAF), p-coumaric acid (CUM), ferulic acid (FER), sinapic acid (SIN), and flavonols: rutin (RUT), isoquercitrin (ISQ), astragalin (AST), myricetin (MYR), quercetin (QUE), kaempferol (KEM), at 250nm and $310 \mathrm{~nm}$. Amounts of compounds were determined based on standard curves. Data were analyzed using one- way analysis of variance (ANOVA), followed by Tukey's post-hoc test using Statistica Software, version 13 (StatSoft, Poland). Statistical differences were calculated at the significance level $p<0.05$ and represented by superscript letters. Analysis were made triplicate.

Benzoic and cinnamic acid derivatives were determined in WML-Pe (Table 1). Among the studied $\mathrm{PhA}$, the following compounds were predominant: CHL and CAF, while among Fla: RUT, similarly to Tunisian and Spanish leaves (SÁNCHEZSALCEDO et al., 2015; THABTI et al., 2012). The study of HUNYADI et al. (2012) has already demonstrated that CHL and RUT are responsible for the antidiabetic properties of white mulberry leaves. In the course of the experiment, the trials were not hydrolyzed, that may have caused MYR, QUE, KEM were not detected in any samples as they remained in the bound form.

The CAF content increased by $64 \%$, while the content of CHL by $16 \%$ as the effect of $60 \mathrm{AD}$, compared to $30 \mathrm{AD}$. CHL is subject to disintegration to i.a. caffeic and quinic acid as a result of technological procedures (RADOJKOVIĆ et al., 2016), which may explain the considerable increase of CAF observed in the study for 60AD samples. At the same time, an increase of the $\mathrm{PhA}$ and Fla content after 60AD application indicates the disintegration of more complex polyphenol complexes. KATSUBE et al. (2009) noted that in drying at $60^{\circ} \mathrm{C}$ certain polyphenols are synthesized, which influences the increase of antioxidative activity. The content of the remaining PhA was also subject to total increase by $\sim 16 \%$ (60AD). Moreover, we have already described that the temperature of $60{ }^{\circ} \mathrm{C}$ gave the best results in antioxidants test in that kind of plant material (PRZEOR \& FLACZYK, 2011). In 90AD samples, we observed a reduction of the discussed PhA by $8 \%$ (CHL) and 25\% (CAF) relative to 30AD samples.

In the case of Fla only for ISQ and AST significantly higher values in 60AD samples were determined, by $17 \%$ and $41 \%$, respectively. Drying at $90{ }^{\circ} \mathrm{C}$ resulted in reduced ISQ and AST content relative to $60 \mathrm{AD}$ samples. In temperature as high as $90{ }^{\circ} \mathrm{C}$, certain $\mathrm{PhA}$ and Fla with antioxidative activity could have decomposed, similarly to KATSUBE et al. (2009).

To sum up, white mulberry leaf drying temperature influenced the $\mathrm{PhA}$ and Fla content in their aqueous extracts. The same PhA and Fla were predominant in the white mulberry var. zolwinska wielkolistna as in the leaves collected in other climatic zones. Air drying at $60{ }^{\circ} \mathrm{C}$ favored the release of $\mathrm{PhA}$ and Fla from compound complexes and/or formation 
Table 1 - Phenolic Acids (PhA) and flavonols (Fla) content in WML-Pe depending on drying temperature.

\begin{tabular}{|c|c|c|c|}
\hline \multirow[t]{2}{*}{ mg per $g$ of extract } & \multicolumn{3}{|c|}{ 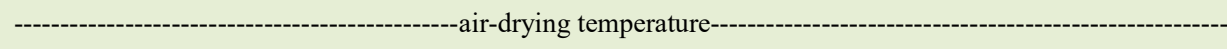 } \\
\hline & $30 \mathrm{C}(30 \mathrm{AD})$ & $60 \mathrm{C}(60 \mathrm{AD})$ & $90 \mathrm{C}(90 \mathrm{AD})$ \\
\hline \multicolumn{4}{|c|}{ 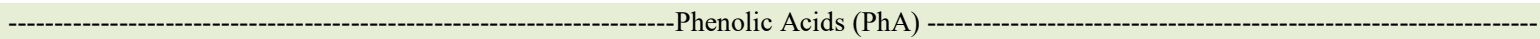 } \\
\hline GAL & $0.018^{\mathrm{a}} \pm 0.002$ & $0.019^{\mathrm{a}} \pm 0.001$ & $0.018^{\mathrm{a}} \pm 0.001$ \\
\hline PRO & $0.156^{\mathrm{a}} \pm 0.012$ & $0.166^{\mathrm{a}} \pm 0.010$ & $0.165^{\mathrm{a}} \pm 0.014$ \\
\hline HYD & $0.111^{\mathrm{a}} \pm 0.010$ & $0.112^{\mathrm{a}} \pm 0.009$ & $0.135^{\mathrm{b}} \pm 0.002$ \\
\hline VAN & $0.761^{\mathrm{b}} \pm 0.009$ & $0.771^{b} \pm 0.016$ & $0.647^{\mathrm{a}} \pm 0.015$ \\
\hline CHL & $4.624^{b} \pm 0.014$ & $5.388^{\mathrm{c}} \pm 0.032$ & $4.270^{\mathrm{a}} \pm 0.062$ \\
\hline CAF & $2.540^{\mathrm{b}} \pm 0.019$ & $4.175^{c} \pm 0.021$ & $1.901^{\mathrm{a}} \pm 0.027$ \\
\hline CUM & $0.271^{\mathrm{a}} \pm 0.004$ & $0.424^{b} \pm 0.043$ & $0.253^{\mathrm{a}} \pm 0.008$ \\
\hline FER & $0.391^{\mathrm{a}} \pm 0.005$ & $0.379^{\mathrm{a}} \pm 0.028$ & $0.345^{\mathrm{a}} \pm 0.018$ \\
\hline SIN & $0.214^{\mathrm{a}} \pm 0.003$ & $0.377^{\mathrm{b}} \pm 0.007$ & $0.405^{b} \pm 0.101$ \\
\hline \multicolumn{4}{|c|}{ 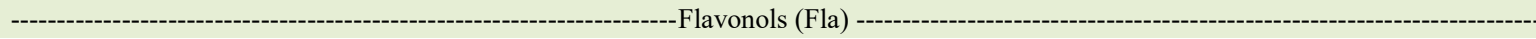 } \\
\hline RUT & $2.598^{\mathrm{a}} \pm 0.068$ & $2.413^{\mathrm{a}} \pm 0.134$ & $2.377^{\mathrm{a}} \pm 0.092$ \\
\hline ISQ & $1.133^{\mathrm{a}} \pm 0.018$ & $1.323^{\mathrm{b}} \pm 0.052$ & $1.260^{\mathrm{a}} \pm 0.016$ \\
\hline AST & $0.768^{\mathrm{a}} \pm 0.153$ & $1.081^{\mathrm{b}} \pm 0.044$ & $0.867^{\mathrm{a}} \pm 0.025$ \\
\hline MYR & $0.000^{\mathrm{a}} \pm 0.000$ & $0.000^{\mathrm{a}} \pm 0.000$ & $0.000^{\mathrm{a}} \pm 0.000$ \\
\hline QUE & $0.000^{\mathrm{a}} \pm 0.000$ & $0.000^{\mathrm{a}} \pm 0.000$ & $0.000^{\mathrm{a}} \pm 0.000$ \\
\hline KEM & $0.000^{\mathrm{a}} \pm 0.000$ & $0.000^{\mathrm{a}} \pm 0.000$ & $0.000^{\mathrm{a}} \pm 0.000$ \\
\hline
\end{tabular}

$\mathrm{a}, \mathrm{b}, \mathrm{c}$ - different letters show statistically significant differences in Tukey's test, $\mathrm{p}<0.05$.

WML-Pe - extracts from white mulberry (Morus alba L.) leaves Polish var. zolwinska wielkolistna; AD - air-drying temperature; GAL gallic acid; PRO - protocatechuic acid; HYD - 4-hydroxybenzoic acid; VAN - vanillic acid; CHL - chlorogenic acid; CAF - caffeic acid; CUM - p-coumaric acid; FER - ferulic acid; SIN - sinapic acid; RUT - rutin; ISQ - isoquercitrin; AST - astragalin; MYR - myricetin; QUE - quercetin; KEM - kaempferol.

of new compounds, which resulted in their elevated content, in total by $22 \%$, relative to leaves dried at 30 ${ }^{\circ} \mathrm{C}$, whereas drying the leaves at $90{ }^{\circ} \mathrm{C}$ reduced their content. Drying at $60{ }^{\circ} \mathrm{C}$ had the highest efficiency in terms of $\mathrm{PhA}$ and Fla contents determined with HPLC/DAD. Our studies indicated that air-drying at temperature of $60{ }^{\circ} \mathrm{C}$ is the optimum for mulberry leaves. However, these studies did not analyze the effects of other, similar temperatures, e.g. $50{ }^{\circ} \mathrm{C}, 70$ ${ }^{\circ} \mathrm{C}$ on PhA and Fla contents. Results obtained here are the appropriate background to precisely determine the ideal WML-P drying temperature. These findings will bring beneficial information for the improvement of mulberry leaf production. Moreover, this way of drying leaves, is feasible for an average Polish herbs manufacturer. However, further studies are needed eg. for other $\left(50{ }^{\circ} \mathrm{C}, 55{ }^{\circ} \mathrm{C}, 65{ }^{\circ} \mathrm{C}, 70{ }^{\circ} \mathrm{C}\right)$ drying temperatures or to determine the effect of drying on the antidiabetic activity.

\section{ACKNOWLEDGEMENTS}

This study was financed by Department of Gastronomy Science and Functional Foods, Poznan University of Life Sciences, Poland.

\section{DECLARATION OF CONFLICT OF INTERESTS}

The authors declare no conflict of interest. The founding sponsors had no role in the design of the study; in the collection, analyses, or interpretation of data; in the writing of the manuscript, and in the decision to publish the results.

\section{AUTHORS' CONTRIBUTIONS}

The authors contributed equally to the manuscript.

\section{REFERENCES}

BUTT, M. S. et al. Morus alba L. nature's functional tonic. Trends in Food Science and Technology, v.19, n.10, p.505-512, 2008. Available from: <http://dx.doi.org/10.1016/j.tifs.2008.06.002>. Accessed: May, 05, 2012. doi: 10.1016/j.tifs.2008.06.002.

CHAN, E. W. C.; LYE, P. Y.; WONG, S. K. Phytochemistry, pharmacology, and clinical trials of Morus alba. Chinese Journal of Natural Medicines, v.14, n.1, p.17-30, 2016. Available from: $<$ http://dx.doi.org/10.3724/SP.J.1009.2016.00017>. Accessed: May, 06, 2017. doi: 10.3724/SP.J.1009.2016.00017.

HOSSAIN, M. B. et al. Effect of drying method on the antioxidant capacity of six Lamiaceae herbs. Food Chemistry, v.123, n.1, p.85-91, 2010. Available from: <http://dx.doi.org/10.1016/J. 
FOODCHEM.2010.04.003>. Accessed: May, 06, 2017. doi: 10.1016/J.FOODCHEM.2010.04.003.

HUNYADI, A. et al. Chlorogenic acid and rutin play a major role in the in vivo anti-diabetic activity of Morus alba leaf extract on type II diabetic rats. PloS one, v.7, n.11, p.e50619, 2012. Available from: $<$ http://dx.doi.org/10.1371/journal.pone.0050619>. Accessed: May, 05, 2014. doi: 10.1371/journal.pone.0050619.

IQBAL, S. et al. Proximate composition and antioxidant potential of leaves from three varieties of Mulberry (Morus sp.): a comparative study. International Journal of Molecular Sciences, v.13, n.6, p.6651-64, 2012. Available from: <http:// dx.doi.org/10.3390/ijms13066651>. Accessed: May, 10, 2014. doi: $10.3390 /$ ijms 13066651 .

KATSUBE, T. et al. Effect of air-drying temperature on antioxidant capacity and stability of polyphenolic compounds in mulberry (Morus alba L.) leaves. Food Chemistry, v.113, n.4, p.964-969, 2009. Available from: <http://dx.doi.org/10.1016/j. foodchem.2008.08.041>. Accessed: Feb. 15, 2012. doi: 10.1016/j. foodchem.2008.08.041.

KOBUS, J. et al. Phenolic compounds and antioxidant activity of extracts of Ginkgo leaves. European Journal of Lipid Science and Technology, v.111, p.1140-1150, 2009. Available from: $<$ http://dx.doi.org/10.1002/ejlt.200800299>. Accessed: Jun. 14, 2015. doi: 10.1002/ejlt.200800299.

KOBUS-CISOWSKA, J. et al. Composition of polyphenols of asparagus spears (Asparagus officinalis) and their antioxidant potential. Ciência Rural, v.49, n.4, p.e20180863, 2019. Available from: <http://dx.doi.org/10.1590/0103-8478cr20180863>. Accessed: Jun. 10, 2019. doi: 10.1590/0103-8478cr20180863.

KUJAWSKA, M. et al. Protective effect of Morus alba leaf extract on $\mathrm{N}$-nitrosodiethylamine-induced hepatocarcinogenesis in rats. In Vivo, v.30, n.6, p.807-812, 2016. Available from: <http:// dx.doi.org/10.21873/invivo.10998>. Accessed: Jan. 6, 2017. doi: 10.21873/invivo.10998.

LEMUS-MONDACA, R. et al. Antioxidant, antimicrobial and anti-inflammatory potential of Stevia rebaudiana leaves: effect of different drying methods. Journal of Applied Research on Medicinal and Aromatic Plants, v.11, p.37-46, 2018. Available from: <http://dx.doi.org/10.1016/j.jarmap.2018.10.003>. Accessed: Jan. 7, 2019. doi: 10.1016/j.jarmap.2018.10.003.

PRZEOR, M.; FLACZYK, E. Wpływ temperatury suszenia pędów i liści morwy białej (Morus alba) na aktywność przeciwutleniającą.
Zeszyty Problemowe Postępów Nauk Rolniczych, v.569, p.277-283, 2011. Available from: <http://zppnr.sggw.pl/569.pdf>. Accessed: Dec. 22, 2011.

PRZEOR, M.; FLACZYK, E. Antioxidant properties of Paratha type flat bread enriched with white mulberry leaf extract. Indian Journal of Traditional Knowledge, v.15, n.2, p.237-244, 2016. Available from: <http://nopr.niscair.res.in/ handle/123456789/33974>. Accessed: Aug. 5, 2016.

QIN, P. et al. Changes in phytochemical compositions, antioxidant and $\alpha$-glucosidase inhibitory activities during the processing of tartary buckwheat tea. Food Research International, v.50, n.2, p.562-567, 2013. Available from: <http://dx.doi.org/10.1016/j. foodres.2011.03.028>. Accessed: Jun. 10, 2015. doi: 10.1016/j. foodres.2011.03.028.

RADOJKOVIĆ, M. et al. Biological activities and chemical composition of Morus leaves extracts obtained by maceration and supercritical fluid extraction. The Journal of Supercritical Fluids, v.117, p.50-58, 2016. Available from: <http://dx.doi. org/10.1016/J.SUPFLU.2016.05.004>. Accessed: May, 21, 2017. doi: 10.1016/J.SUPFLU.2016.05.004.

SÁNCHEZ-SALCEDO, E. et al. (Poly)phenolic compounds and antioxidant activity of white (Morus alba) and black (Morus nigra) mulberry leaves: Their potential for new products rich in phytochemicals. Journal of Functional Foods, v.18, p. 039-1046, 2015. Available from: $<$ http://dx.doi.org/10.1016/J.JFF.2015.03.053>. Accessed: Apr. 15, 2016. doi: 10.1016/J.JFF.2015.03.053.

SIGER, A. et al. Zawartość związków fenolowych w nowych odmianach rzepaku. Rośliny Oleiste, 2004. v.25, p.263-274. Available from: <http://biblioteka.ihar.edu.pl/oilseed_crops. php?field[slowa kluczowe $]=\&$ field $[$ autor $]=\& i d=1 \&$ idd $=70 \&$ podz ial_id=1\&podzial_idd=2\#lib>. Accessed: May, 13, 2012.

THABTI, I. et al. Identification and quantification of phenolic acids and flavonol glycosides in Tunisian Morus species by HPLCDAD and HPLC-MS. Journal of Functional Foods, v.4, n.1, p.367-374, 2012. Available from: <http://dx.doi.org/10.1016/j. jff.2012.01.006>. Accessed: Jun. 02, 2014. doi: 10.1016/j. jff.2012.01.006.

ZOU, Y.-X. The roles of fermentation technologies in mulberry foods processing: application and outlooks. Medicinal Chemistry, v.5, n.4, p.4-5, 2015. Available from: <http://dx.doi. org/10.4172/2161-0444.1000e107>. Accessed: Jul. 24, 2016. doi: $10.4172 / 2161-0444.1000 \mathrm{e} 107$. 